\title{
Diabetes Mellitus in the Chinese Hamster
}

\author{
I. Metabolic and Morphologic Studies
}

\author{
Ethan A.H. Sims, and Bernard R. Landau
}

Departments of Medicine and Biochemistry, Western Reserve University School of Medicine, Cleveland, Ohio, U. S.A., and Department of Medicine, College of Medicine, University of Vermont, Burlington, Vermont, U.S.A.

Summary. Liver, diaphragm, heart, kidney, and adipose tissue of five Chinese hamsters with diabetes of varying severity have been studied by incubation in vitro with glucose-U-, 1-, 2-, or $6-{ }^{14} \mathrm{C}$, pyruvate-2- ${ }^{14} \mathrm{C}$, and bicarbonate $-{ }^{14} \mathrm{C}$ in various combinations. The pancreas and kidney were examined by electron microscopy. There was no histologic evidence of hypertrophy of the pancreatic islets; extractable insulin was reduced, and plasma insulin was relatively reduced. There was no consistent microangiopathy of insular capillaries. Both the mild and severely diabetic hamsters had a reduction in the incorporation of the carbons of glucose and of pyruvate into $\mathrm{CO}_{2}$, glycogen, and fatty acids in the liver, and, at least in severely diabetic animals, of oxidation of glucose to $\mathrm{CO}_{2}$ in muscle. There was no change consequent to diabotes in the metabolism of adipose tissue, except for a possible decrease in pentose cycle activity. The kidneys of the diabetic hamsters had less incorporation of carbon-2 of pyruvate into $\mathrm{CO}_{2}$, but otherwise no biochemical changes were evident. Both muscle and adipose tissue were responsive in vitro to insulin when tested with greater physiologic amounts. While the possibility cannot be excluded that a transient earlier phase with hypersecretion of insulin escaped detection, the changes in this limited number of diabetic hamsters parallel those previously found in rats with experimental chronic deficiency of insulin.

Diabète sucré du hamster chinois: $I$. Etudes métaboliques et morphologiques.

Résumé. Nous avons étudié le foie, le diaphragme, le coeur, le rein et le tissu adipeux de 5 hamsters chinois avec diabète plus ou moins sévère, en incubant ce tissu in vitro avec du glucose uniformément marqué au ${ }^{14} \mathrm{C}$, ou marqué on positions 1-, 2-, ou 6-, avee du pyruvate-2- ${ }^{14} \mathrm{C}$, ou avec du bicarbonate- ${ }^{14} \mathrm{C}$, diversement combinés. Nous avons également examiné au microscope électronique le pancréas et le rein de ces animaux. Nous n'avons pas trouvé d'indication histologique d'hypertrophie des îlots pancréatiques, le contenu en insuline du pancréas étant diminué et l'insuline plasmatique relativement diminuée également. Nous n'avons pas non plus trouvé régulièrement une microangiopathie des capillaires des îlots. Le foie de hamsters diabétiques de type sévère ou léger incorpore moins les carbones du glucose et du pyruvate dans le $\mathrm{CO}_{2}$, le glycogène et les acides gras. De même, le muscle des animaux avec un diabète sévère oxyde moins de glucose en $\mathrm{CO}_{2}$. Par contre, le tissu adipeux des animaux diabétiques ne se distingue pas de celui d'animaux normaux, peut-être à l'exception d'une diminution d'activité du cycle des pentoses. Le tissu rénal des hamsters diabétiques incorpore moins de carbbone-2 du pyruvate dans le $\mathrm{CO}_{2}$, mais son comportement est par ailleurs normal. Une réponse à l'insuline a été observée in vitro tant pour le muscle que pour le tissu adi- peux, alors que les concentrations d'insuline employées étaient élevées. Malgré le petit nombre de hamsters étudiés, il est permis de conclure que ces altérations sont comparables à celles déjà observées chez des rats souffrant d'une carence insulinique chronique expérimentale. Bien qu'il ne soit pas possible d'exclure qu'il $y$ ait eu une première phase transitoire et non détectée, caractérisée par une hypersécrétion insulinique, nous pensons plutôt que nos observations dans ce petit groupe d'animaux diabétiques sont apparentées à celles faites préalablement chez des rats avec déficience chronique en insuline induite expérimentalement.

Diabetes mellitus beim chinesischen Hamster: I. Morphologische und Stoffwechsel-Studien.

Zusammenfassung. Leber, Zwerchfell, Herz, Niere und Fettgewebe von 5 chinesischen Hamstern mit Diabetes verschiedenen Schweregrades wurden in vitro inkubiert. Glucose-U, 1-, 2-, oder ${ }^{6-14} \mathrm{C}$, Pyruvat-2-14 $\mathrm{C}$ und Bicarbonat- ${ }^{14} \mathrm{C}$ wurden in verschiedenen Kombinationen als $\mathrm{Sub}$ strat verwandt. Pankreas und Niere wurden elektronenmikroskopisch untersucht. Eine Hypertrohpie der Pankreasinseln war histologisch nicht nachweisbar. Extrahierbares Insulin war vermindert und Plasma-Insulinwerte verhältnismäßig niedrig. Eine regelmäßige Mikroangiopathie der Inselkapillaren konnte nicht beobachtet werden. Sowohl die leicht-als auch die schwer-diabetischen Hamster zeigten einen verminderten Finbau von Glucose-sowie von Pyruvat-Kohlenstoff in $\mathrm{CO}_{2}$, Glykogen und Fettsäuren durch die Leber. Eine herabgesetzte Oxydation von Glucose zu $\mathrm{CO}_{2}$ durch den $M$ uskel war zumin dest in schwer-diabetischen Tieren nachweisbar. Der Stoffwechsel des Fettgewebes war durch den. Diabetes nicht beeinflußt; die Aktivität des Pentosezyklus war möglicherweise herabgesetzt. Das Nierengewebe des diabetischen Hamsters zeigte einen geringeren Einbau vom C-2 des Pyruvats in $\mathrm{CO}_{2}$, jedoch konnten sonst keine biochemischen Veränderungen festgestellt werden. Muskelund Fettegewebe sprachen im in vitro Versuch auf relativ hohe Insulinkonzentrationen gut an. Die Resultate, die wir aus den Untersuchungen einer begrenzten Anzahl von Hamstern erhielten, entsprechen somit früheren Beobachtungen bei Ratten mit experimentell bedingtem chronischen Insulinmangel. Es besteht allerdings die Möglickeit, daß uns eine vorübergehende frühere Phase mit Hypersekretion von Insulin unbemerkt entging.

Key-words: Spontaneous diabetes, Chinese hamster, Cricetulus griseus, Liver in vitro, Diaphragm in vitro, Heart in vitro, Kidney in vitro, Adipose tissue in vitro, Glucose metabolism in vitro, Pyruvate metabolism, Bicarbonate metabolism, Microangiopathy, Prediabetes.
A majority of the studies of diabetes mellitus in animals have been limited to the acute changes resulting from pancreatectomy, damage to the islet tissue from alloxan or anti-insulin serum. Thus they may not reflect the changes in spontaneous diabetes in animals and in man, in which there may be a relative and not absolute deficiency of insulin. Most of the previous studies of spontaneous diabetes in animals have 
been made at a late stage of the disease, so that the earliest and probably most informative changes may have been obscured.

Yergantan, Meier and Gagnon (1957) and YERGaNIAN (1964) reported spontaneous diabetes mellitus in a strain of Chinese hamsters. In its severity, early onset, and tendency toward ketosis it resembled the so-called juvenile diabetes in man. The course of the disease differs from that in the majority of animal species in that obesity does not develop during the incipient stages and in contrast to the response of the sand rat (HACKEL et al., 1966) a high caloric diet does not readily precipitate diabetes. Since the disease in the hamster is similar to one of the syndromes of diabetes in man, we have studied the disorder in its early and late stages, comparing the metabolism of the major tissues by application of the techniques that have been previously applied to the iatrogenic forms of the disorder. Particular emphasis has been placed on examining animals as soon as possible after the onset of overt diabetes has been established, to determine in which tissue abnormalities first appear. When possible, serum and pancreas have been analyzed for insulin content. We have also examined several of the tissues by electon microscopy to detect early vascular or other changes and to correlate their morphology with their biochemical changes.

\section{Materials}

Five diabetic Chinese hamsters were obtained from the colony at the University of Vermont. An additional animal that had shown glucosuria was kindly supplied from the colony of Dr. OTTo SIREK at the University of Toronto. In each study a hamster, matched with respect to age, sex, and weight was treated identically and served as a control. The diabetic hamsters of the Vermont colony were derived from a pair from the strains HG, AS-3 and VSY generously provided by Dr. George Yerganian at the Children's Medical Center in Boston. Control animals, from the same source and the lines 8-Aa-5 and 7-D-5, were derived from a strain that had been free of diabetes, but one of five offspring of the control animal of experiment B-2 subsequently became diabetic, so that the animals cannot be considered free of the genetic trait.

All ${ }^{14} \mathrm{C}$-labelled substrates were purchased from the New England Nuclear Corporation, Boston, Massachusetts.

\section{Methods}

Complete records of breeding, appearance of glucosuria, and weight were kept at the parent colonies. For 7 to 30 days prior to study the animals were placed in a metabolic cage and their weight and urine volume were determined. Urinary glucose was detected by Clinistix (Ames Company) and ketone bodies by Acetest tablets (Ames Company). The animals were fed Purina rat pellets and wheat germ until the time of killing, at which time every animal was found to have food in its stomach. An animal was considered to be diabetic when exhibiting hyperglycemia and glucosuria above $10 \mathrm{mg}$ per day. The animals were anesthetized with intramuscular nembutal $(60 \mathrm{mg}$ per $\mathrm{kg}$ ) and perhaps fortuitously each pair appeared to exihibit a comparable degree and duration of physical excitement prior to narcosis. They were laparotomized and exanguinated by withdrawal of blood from the vena cava into a heparinized syringe. Following exsanguination tissues were quickly removed in the following order: liver, pancreas, adrenal, kidney, epididymal fat pads in the male, diaphragm, heart, skeletal muscle and thyroid. Seations from each of the tissues except diaphragm and adipose tissue were taken for light and electronmicroscopy. Biochemical studies were performed on liver, diaphragm, heart, kidney, and adipose tissue.

\section{A. Biochemical procedures}

Liver. When glucose was the substrate, each flask contained $2 \mathrm{ml}$. of a medium with the following ionic composition (mM/L): $\mathrm{K}^{+} 110 ; \mathrm{Mg}^{++} 20 ; \mathrm{Ca}^{++} 10 ;$ $\mathrm{HCO}_{3}-40$; and $\mathrm{Cl}-130$ (HASTINGs et al., 1952). Glucose${ }^{14} \mathrm{C}$ was added in a concentration of $20 \mu$ moles $/ \mathrm{ml}$ labelled either uniformly or in carbon 1 or 6 . Pyruvate${ }^{14} \mathrm{C}$ was added in a concentration of $40 \mu \mathrm{moles} / \mathrm{ml}$ to a medium differing only in that the chloride concentration was $90 \mu \mathrm{moles} / \mathrm{ml}$. In an additional flask the pyruvate was unlabelled, but the bicarbonate was labelled with ${ }^{14} \mathrm{C}$. The livers were sliced with a StadieRiggs microtome and $100-150 \mathrm{mg}$ was distributed into each of the flasks. After incubation for 2 hours sulphuric acid was added and the evolved ${ }^{14} \mathrm{CO}_{2}$ collected in hyamine and assayed for ${ }^{14} \mathrm{C}$. Following digestion of the slices in 30 per cent $\mathrm{KOH}$, glycogen and fatty acid were isolated, and incorporation of ${ }^{14} \mathrm{C}$ was determined by assay on planchets of the radioactivity of glucosazones prepared from glucose of the glycogen or directly from the fatty acids. Glycogen content was determined in unincubated slices of tissue and in the incubated slices at the completion of incubation (AsHMrore et al., 1957). In one experiment in which glucose-2- ${ }^{14} \mathrm{C}$ was the substrate the glucose from glycogen was degraded using Leuconostoc mesenteroides to yield the ${ }^{14} \mathrm{C}$ activity in each carbon of glucose (LAN DAU, BARTSCH and WILLIAMIS, 1966).

Diaphragm. One hemidiaphragm, ranging in weight from 21 to $47 \mathrm{mg}$ was incubated in $2 \mathrm{ml}$ of a modified Krebs-Ringer bicarbonate buffer (CoHEN, 1959), containing glucose-U- ${ }^{14} \mathrm{C}$ and the contralateral hemidiaphragm was incubated identically, except that $0.1 \mathrm{U}$. of insulin was added to the medium. Incubation was terminated after 2 hours and the ${ }^{14} \mathrm{C}$ of ${ }^{14} \mathrm{C}_{2}$ was assayed as above for liver (LANDAU, BARTSCH and Wurctams, 1966). The glucose from glycogen was assayed as its osazone (AsHMone et al., 1956).

Heart. Slices of heart 100 to $160 \mathrm{mg}$ in weight were also incubated in $2 \mathrm{ml}$ of Krebs-Ringer bicarbonate medium containing $5 \mu \mathrm{M} / \mathrm{ml}$ of glucose-U- ${ }^{14} \mathrm{C}$, and 
after 2 hours of incubation incorporation of radioactive carbon into glycogen and $\mathrm{CO}_{2}$ was measured in the same manner as for diaphragm.

Kidney. The kidneys were sliced and from 120 to $180 \mathrm{mg}$ of tissue was incubated in $2 \mathrm{ml}$ of KrebsRinger bicarbonate solution containing pyruvate-2${ }^{14} \mathrm{C}(40 \mu \mathrm{M} / \mathrm{ml})$. After 2 hours ${ }^{14} \mathrm{CO}_{2}$ was evolved into hyamine and assayed. Glucose was isolated by paper chromatography from the medium after deionization and degraded by Leuconostoc mesenteroides to yield the ${ }^{14} \mathrm{C}$ activity in each carbon of the glucose (LANDAU, BARTSCH and WHLIAMS, 1966).

Adipose tissue. Adipose tissue from one epididymal fat pad, ranging widely in weight from $21 \mathrm{mg}$ in the severe diabetic to $260 \mathrm{mg}$ in the mild diabetic or control animal, was incubated in $1 \mathrm{ml}$ of a modified Krebs bicarbonate buffer containing gelatin $2 \mathrm{mg} / \mathrm{ml}$ (LEONARDs et al., 1962) and $5 \mu$ moles/ml of glucose${ }^{2-}{ }^{14} \mathrm{C}$ and the other pad of fat tissue was incubated in medium identical except that $0.1 \mathrm{U}$ of insulin was added. After 2 hours incubation was terminated by addition of sulphuric acid. Assay was carried out of ${ }^{14} \mathrm{CO}_{2}$ and of incorporation of ${ }^{14} \mathrm{C}$ into lipid and glucose from glycogen, and the glucose was degraded as de. scribed above.

Measurement of uptake of substrate from the medium. When pyruvate-2- ${ }^{14} \mathrm{C}$ was substrate, its 2,4 -dinitrophenylhydrazone was prepared from an aliquot of the medium before and after incubation. The uptake of pyruvate was calculated from the disappearance of ${ }^{14} \mathrm{C}$. When glucose- ${ }^{14} \mathrm{C}$ was substrate the uptake was estimated from the difference in ${ }^{14} \mathrm{C}$ activity in glucosazones prepared from these media.

Assay of ${ }^{14} \mathrm{C}$. The hyamine containing ${ }^{14} \mathrm{CO}_{2}$ was dissolved in a napthalene-dioxane scintillation fluid and assayed for ${ }^{14} \mathrm{C}$ in a liquid scintillation counter (Landau, Bartsch and Wrulams, 1966). Internal standardization was used for quench correction. Glucosazones and 2,4-dinitrophenylhydrazones were plated on stainless steel planchets, which were counted in a gas flow, thin-window counter.

Calculations. Uptakes are expressed as $\mu$ moles $/ g$ of substrate disappearing from the medium per gram weight wet weight of tissue during the 2-hour incubation and have been calculated from the percentage glucose disappearing from the medium, measured as the glucosazone. Oxidation of ${ }^{14} \mathrm{C}$ of substrate to ${ }^{14} \mathrm{CO}_{2}$ and incorporation into glucose from glycogen and lipid are expressed as $\mu$ moles of carbon 1 or 6 of glucose or carbon 2 of pyruvate per gram per the period of incubation. When glucose-U. ${ }^{14} \mathrm{C}$ was substrate incorporations are expressed as $\mu$ moles of glucose $-{ }^{14} \mathrm{C}$ per gram per period of incubation.

Analyses of blood and urine. Immunoassay of insulin was performed by a modification of the double-antibody method of Morgan and Lazarow (SoELDNER and SLoNe, 1965) and in one instance (B-2) insulin-like activity of the pancreas was bioassayed using rat epididymal fat pads (LeONARDS, LANDAU and
BARTSCH, 1962) through the courtesy of Dr. LEONARDS and of the plasma by the method of YaLow and Berson (1960) through the courtesy of Dr. BeRsoN. Blood glucose was measured by the SomoGYI-NELSON method (Somogrr, 1952) and urine glucose by a glucose-oxidase method (WAsHKo and RICE, 1964). Plasma triglycerides were measured by the method of CARLSON and WADSTRöm (1959) in the laboratory of Dr. W. Irsulu. The pancreases, excepting the small portion taken for microscopy, were frozen at $-15^{\circ} \mathrm{C}$. and later, insulin was extracted with acid alcohol according to the method of SCOTT and FISHER as modified by LabUSCHAGNe and WRENSHaLL (1957).

\section{B. Morphological Procedures}

Immediately upon removal from the animal, tissue samples were finely diced in 1 per cent osmium tetraoxide buffered to $\mathrm{pH}$ 7.2, fixed, dehydrated, and stored in 95 per cent alcohol until later embedding in epoxyaraldite resin (PeAse, 1965). Sections were cut with a Porter-Blum microtome and were examined a Phillips Model 100B electron microscope. Additional sections were preserved in 10 per cent formalin for light microscopy by conventional methods.

\section{Results}

The historical and laboratory data characterizing the five pairs of diabetic and control animals are given in Table 1. Two animals, T-1 and B-2, had minimal polyuria, blood sugar between 192 and $264 \mathrm{mg} \%$ and significant glucosuria and are therefore considered to be mild diabeties. The three other animals (36, D-2 and CUV-A) had polyuria such that their daily weight of urine frequently exceeded their total body weight. Glucosuria and hyperglycemia were marked, and they are therefore classed as severely diabetic.

\section{Pancreas}

A. Extractable insulin. In all of the diabetic animals including those with mild diabetes the insulin extractable with acid alcohol was greatly reduced in comparison with that of the controls, as assayed by immunoassay or by measurement of insulin-like activity using epididymal fat pad (B-2) (Table 1).

B. Morphology. Electron microscopic findings in the islets of the hamsters with severe diabetes were consistent with those of LusE et al. (1966), reported elsewhere in this symposium. Particular attention was given to the capillaries in or adjacent to the islets. In four diabetic hamsters examined no consistent difference was noted in the thickness or structure of the basement membrane in comparison with that in three non-diabetic controls. The two hamsters with mild diabetes (T-1 and B-2) had prominent, heavily granulated alpha cells, and beta cells were lightly granulated. Occasional beta cells, some with typical lipofucsin accumulations, had prominent Golgi apparatus and dilated endoplasmic reticulum. Glycogen deposition was not prominent. 
Liver

A. Biochemical. In Table 2 is shown the glycogen content initially and after incubation with glucose or pyruvate. Except in one animal with mild diabetes (B-2) the initial content was less in the diabetic animal than in the control, and in general the content was distributions are similar, although there is the suggestion of greater asymmetry in the control than in the diabetic in that the ratios of incorporation of $\mathrm{C} 6 / \mathrm{C} 1$, $\mathrm{C} 5 / \mathrm{C} 2$, and $\mathrm{C4} / \mathrm{C} 3$ are each greater for the control than for the diabetic. The asymmetry suggests a more complete isotopic equilibration of the triose phosphates

Table 1. Historical and laboratory data of diabetic Chinese hamsters

\begin{tabular}{|c|c|c|c|c|c|}
\hline & Mildly diabetic & sters & Severely diabetic & msters & \\
\hline $\begin{array}{l}\text { Experiment no. } \\
\text { Sex } \\
\text { Age (months) } \\
\text { Duration of glucosturia } \\
\text { (months) }\end{array}$ & $\begin{array}{l}\mathrm{T}-1^{1} \\
\mathrm{~F} \\
5 \\
3\end{array}$ & $\begin{array}{l}\mathrm{B}-2^{2} \\
\mathrm{M} \\
18 \\
1.2\end{array}$ & $\begin{array}{l}36 \\
\mathrm{~F} \\
22 \\
1.2\end{array}$ & $\begin{array}{l}\mathrm{D} \cdot 2^{3} \\
\mathrm{M} \\
16 \\
2.2\end{array}$ & $\begin{array}{l}\text { CUV-A4 } \\
M \\
8 \\
4\end{array}$ \\
\hline $\begin{array}{l}\text { Urine } \\
\text { Volume (ml/day) } \\
\text { Total glucose (mg/day) }\end{array}$ & $\begin{array}{l}1.5-2.0 \\
26-0.6 \\
\text { Av. } 10\end{array}$ & $\begin{array}{l}2-5 \\
13-407 \\
\text { Av. } 180\end{array}$ & $\begin{array}{l}35-42 \\
1540,1780 \\
\text { Av. } 1660\end{array}$ & $15-25$ & $\begin{array}{l}27-39 \\
150-1290 \\
\text { Av. } 880\end{array}$ \\
\hline $\begin{array}{l}\text { Plasma } \\
\text { Glucose }(\mathrm{mg} / 100 \mathrm{ml})\end{array}$ & $\begin{array}{l}264 \text { on day } \\
-5 \\
192 \\
\text { Control } 160\end{array}$ & $\begin{array}{l}242 \text { on day } \\
-10 \\
233 \\
\text { Control } 114,87\end{array}$ & $\begin{array}{l}588 \\
\text { Control } 126\end{array}$ & $\begin{array}{l}400 \text { at } \\
\text { Day }-60\end{array}$ & $\begin{array}{l}528 \\
\text { Control } 132\end{array}$ \\
\hline $\begin{array}{l}\text { Triglycerides } \\
(\mathrm{mg} / 100 \mathrm{ml}) \\
\text { Insulin }(\mu \mathrm{U} / \mathrm{ml})\end{array}$ & treated & $\begin{array}{l}88 \\
\text { Control } 60 \\
75 \mu \mathrm{U} \\
\text { Control } 75 \mu \mathrm{U}\end{array}$ & & & $\begin{array}{l}137 \\
\text { Control } 25 \\
\text { treated }\end{array}$ \\
\hline $\begin{array}{l}\text { Pancreas } \\
\text { Extractable } \\
\text { insulin (U/g) }\end{array}$ & & $\begin{array}{l}0.05 \text { (ILA) } \\
\text { Control } 1.87 \text { (ILA) }\end{array}$ & $\begin{array}{l}0.12 \\
\text { Control } 3.03\end{array}$ & & $\begin{array}{l}0.04 \\
\text { Control } 1.16\end{array}$ \\
\hline
\end{tabular}

1 From Toronto Colony. Treated with 1-2 U. NPH insulin from age 2 months to 5 days before study. Mother was insulin-treated diabetic. Father was glucosuric. No ketosis.

a Siblings all diabetic. Maintained weight without insulin. No ketosis.

3 Heavy glucosuria with polyuria.

4 Polyuria subsided to $3-10 \mathrm{ml} /$ day on treatment with $3.5 \mathrm{U}$ to $4 \mathrm{U} \mathrm{NPH}$ insulin. Insulin withdrawn 2 days before study, after which ketosis developed.

Table 2. Glycogen content of the liver $(\mathrm{mg} / \mathrm{g})$ before and after incubation with glucose and pyruvate

\begin{tabular}{|c|c|c|c|c|c|c|}
\hline \multicolumn{4}{|l|}{ Oontrol } & \multicolumn{3}{|l|}{ Diabetic } \\
\hline \multirow{2}{*}{$\begin{array}{l}\text { Experiment } \\
\text { number }\end{array}$} & \multirow{2}{*}{$\begin{array}{l}\text { Initial } \\
\text { content }\end{array}$} & \multicolumn{2}{|c|}{ Substrate } & \multirow{2}{*}{$\begin{array}{l}\text { Initial } \\
\text { Content }\end{array}$} & \multicolumn{2}{|c|}{ Substrate } \\
\hline & & $\overline{\text { Glucose }}$ & Pyruvate & & Glucose & Pyruvate \\
\hline \multicolumn{7}{|c|}{ Mildly diabetic } \\
\hline $\mathrm{T}-1$ & 7.1 & 2.5 & 1.9 & 2.0 & 4.2 & 2.7 \\
\hline B-2 & 4.2 & 8.9 & 7.6 & 7.1 & 4.4 & 5.4 \\
\hline \multicolumn{7}{|c|}{ Severely diabetic } \\
\hline 36 & 15.4 & 4.4 & 4.9 & 0.9 & 0.4 & 0.7 \\
\hline $\mathrm{D}-2$ & lost & 1.1 & 0.9 & lost & 0.1 & 0.1 \\
\hline CUV-A & 5.4 & 3.8 & 4.2 & 1.4 & 0.7 & 0.8 \\
\hline
\end{tabular}

decreased following incubation and to an equal degree regardless of whether glucose or pyruvate was the substrate. Following incubation with ${ }^{14} \mathrm{C}$-labelled glucose, pyruvate, or bicarbonate the incorporation into carbon dioxide, fatty acids, and glycogen was reduced (Table 3 ).

Glycogen from the liver of one of the hamsters with mild diabetes (B-2) was degraded and the percent distribution of ${ }^{14} \mathrm{C}$ in the carbons of glucose derived from $\mathrm{C} 2$ of pyruvate was determined (Table 4 ). The in the diabetic than in the control (LANDAU, HASTINGS and NESBETT, 1955).

$B$. Comment. The present findings are consistent with those of ReNoLd, ZAHND and CHRISTOPHE (1964) in which incorporation of labelled glucose into carbon dioxide, fatty acid and glycogen was found to be reduced in 8 diabetic hamsters with severe diabetes and ketosis. The present studies indicate that this is true in the case of the hamster with mild diabetes as well. 
The distribution in glucose of glycogen derived from $\mathrm{C} 2$ of pyruvate is evidence that the presence of diabetes did not change the quantity of carbon 2 of pyruvate converted directly to glycogen relative to that first entering the Krebs cycle. The distribution in the hamster is similar to that found by TOPPER and HASTINGS (1949) in rabbit liver, and by LANDAU et al. (1955) in rat liver. pared from the final and initial media, the uptake of glucose in the control hamster was $24 \mu$ moles/g of tissue as radioisotopic glucose in the absence and 32.8 in the presence of insulin. In the diabetic hamster the uptakes were $28.4 \mu$ moles and $35 \mu$ moles respectively.

B. Comment. The diaphragm of the diabetic hamster oxidizes less glucose to $\mathrm{CO}_{2}$, regardless of whether the

Table 3. Incorporation ( $\mu$ moles/g/2 hours) of ${ }^{14} \mathrm{C}$ of substrates into carbon dioxide, glycogen, and fatty acids of liver slices

\begin{tabular}{|c|c|c|c|c|c|c|c|}
\hline \multirow{2}{*}{ Experiment } & \multirow{2}{*}{ Substrate } & \multicolumn{2}{|c|}{ Substrate to $\mathrm{CO}_{2}$} & \multicolumn{2}{|c|}{ Substrate to fatty acids } & \multicolumn{2}{|c|}{ Substrate to glycogen } \\
\hline & & $\overline{\text { Control }}$ & Diabetic & Control & Diabetic & Control & Diabetic \\
\hline B-2 & Glucose $-1-{ }^{14} \mathrm{C}$ & 1.5 & 1.1 & 0.09 & 0.02 & 1.4 & 0.3 \\
\hline $\begin{array}{l}36 \\
\text { CUY-A }\end{array}$ & $\begin{array}{l}\text { Glucose }-1-{ }^{14} \mathrm{C} \\
\text { Glucose }-1 .{ }^{14} \mathrm{C}\end{array}$ & $\begin{array}{l}3.2 \\
2.9\end{array}$ & $\begin{array}{l}1.2 \\
1.0\end{array}$ & lost & 0.05 & $\begin{array}{l}8.7 \\
7.9\end{array}$ & $\begin{array}{l}0.1 \\
1.0\end{array}$ \\
\hline B-2 & Glucose $-6-{ }^{14} \mathrm{C}$ & 2.7 & 1.3 & 0.15 & 0.02 & 1.5 & 0.4 \\
\hline $\begin{array}{l}36 \\
\text { CUV-A }\end{array}$ & $\begin{array}{l}\text { Glucose }-6-{ }^{14} \mathrm{C} \\
\text { Glucose }-6-{ }^{-14} \mathrm{C}\end{array}$ & $\begin{array}{l}3.0 \\
4.4\end{array}$ & $\begin{array}{l}0.42 \\
1.9\end{array}$ & 5.1 & 0.14 & $\begin{array}{l}7.6 \\
7.5\end{array}$ & $\begin{array}{l}0.3 \\
0.0\end{array}$ \\
\hline B-2 & Pyruvate-2.14C & 33.9 & 28.7 & 2.7 & 1.4 & 9.9 & 8.4 \\
\hline $\begin{array}{l}36 \\
\text { CUV-A }\end{array}$ & $\begin{array}{l}\text { Pyruvate- } 2-{ }^{14} \mathrm{C} \\
\text { Pyruvate-2-214 } \mathrm{C}\end{array}$ & $\begin{array}{l}29.4 \\
61.3\end{array}$ & $\begin{array}{l}27.5 \\
53.4\end{array}$ & 3.4 & 0.9 & $\begin{array}{l}4.5 \\
4.6\end{array}$ & $\begin{array}{l}2.7 \\
1.4\end{array}$ \\
\hline $\mathrm{B}-2$ & Bicarbonate $-{ }^{14} \mathrm{C}$ & & & 0.07 & 0.04 & 13.4 & 11.5 \\
\hline $\begin{array}{l}36 \\
\text { CUV.A }\end{array}$ & $\begin{array}{l}\text { Bicarbonate }-{ }^{14} \mathrm{C} \\
\text { Bicarbonate- }{ }^{14} \mathrm{C}\end{array}$ & & & 0.03 & 0.07 & $\begin{array}{l}4.5 \\
1.6\end{array}$ & $\begin{array}{l}3.0 \\
0.3\end{array}$ \\
\hline
\end{tabular}

Table 4. Distribution of ${ }^{14} \mathrm{C}$ in glycogen from slices of liver after incubation with pyruvate-2-14C

\begin{tabular}{llllllll}
\hline Carbons & 1 & 2 & 3 & 4 & 5 & 6 & $\begin{array}{c}\text { Per cent } \\
\text { recovery }\end{array}$ \\
\hline Control & 18.2 & 20.2 & 9.3 & 11.0 & 21.7 & 19.5 & 93.2 \\
Diabetic (B-2) & 18.9 & 21.4 & 9.4 & 10.1 & 21.2 & 18.9 & 97.6
\end{tabular}

Table 5. Incorporation ( $\mu$ moles/g/ 2 hours) of glucose- $U-{ }^{14} \mathrm{C}$ into carbon dioxide and glycogen of diaphragm

\begin{tabular}{|c|c|c|c|c|c|c|c|c|}
\hline \multirow[t]{2}{*}{ Experiment } & \multicolumn{4}{|c|}{$\begin{array}{l}\text { Glucose- } \mathrm{U}^{14} \mathrm{C} \text { to } \mathrm{CO}_{\mathrm{a}} \\
\text { control diabetic }\end{array}$} & \multicolumn{4}{|c|}{$\begin{array}{l}\text { Glucose- } \mathrm{U} \cdot{ }^{14} \mathrm{C} \text { to Glycogen } \\
\text { control diabetic }\end{array}$} \\
\hline & - & + & - & + & - & + & - & + \\
\hline \multicolumn{9}{|l|}{ Mildly diabetic } \\
\hline $\mathrm{T}-1$ & 5.8 & 7.3 & 4.3 & lost & 1.4 & 2.3 & 1.5 & 2.3 \\
\hline B-2 & 4.4 & 4.5 & 3.1 & 3.8 & 4.6 & 10.1 & 4.9 & 8.0 \\
\hline \multicolumn{9}{|l|}{ Severely diabetic } \\
\hline 36 & 6.9 & 9.0 & 1.1 & 1.4 & 4.3 & 6.9 & 4.9 & 10.3 \\
\hline $\mathrm{D} .2$ & 2.4 & 3.7 & 1.4 & 1.1 & 4.1 & 5.1 & 2.8 & 3.1 \\
\hline CUV -A & 7.5 & 9.1 & 2.4 & 2.9 & 5.4 & 8.7 & 2.9 & 4.6 \\
\hline
\end{tabular}

\section{Diaphragm}

A. Biochemical. There was no significant difference in incorporation of glucose-U. ${ }^{14} \mathrm{C}$ into glycogen of diaphragm (Table 5). Both diabetic and normal had similar increase in incorporation when insulin was added to the medium. On the other hand, oxidation of glucose-U- ${ }^{14} \mathrm{C}$ to $\mathrm{CO}_{2}$ was less in the diabetic for each pair of animals. Insulin slightly enhanced this incorporation in all the normals and in 3 of 4 diabetic animals in which it was measured. As calculated from the difference in ${ }^{14} \mathrm{C}$ activity of the glucosazones pre- diabetes is mild or severe. Beloff-Chatr et al. (1955) and Mortwakt and Landau (1962) did not observe differences in oxidation of glucose to $\mathrm{CO}_{2}$ using the rat cut diaphragm nor did they increases in $\mathrm{CO}_{2}$ formation after addition of insulin, although this is suggested by the present data using the hamster diaphragm and has been observed in the rat by VILLEE and Hastings (1949). The uptake of glucose by the diaphragm represents less than 20 per cent of the glucose added and changes after addition of insulin and with diabetes could be difficult to detect. 
Heart

A. Biochemical. (Table 6). In the severely diabetic animals (D-2 and CUV-A) there was a decrease in the production of ${ }^{14} \mathrm{CO}_{2}$ from glucose-U- ${ }^{14} \mathrm{C}$, but no difference was found in the mildly diabetic animals (T-1 and B-2). There was no consistent difference in the incorporation of glucose into glycogen in the mild or severe diabetics. Uptake of glucose from the medium, determined through osazone formation averaged 8.0 $\mu$ moles $/ g$ for the control tissues and $7.6 \mu$ moles $/ g$ for the diabetic tissues.

$B$. Comment. The metabolism of glucose in the heart was similar to that in the diaphragm, particularly with respect to the decrease in formation of $\mathrm{CO}_{2}$ in the diabetic as compared with the normal.

\section{Kidney}

A. Biochemical. The sparse data obtained (Table 7) suggest a decrease in incorporation of ${ }^{14} \mathrm{C}$ from pyruvate-2- ${ }^{14} \mathrm{C}$ into $\mathrm{CO}_{2}$, but not into glycogen. During the

Table. 6. Incorporation ( $\mu$ moles/g/2 hours) of glucose- $U-{ }^{14} \mathrm{C}$ into carbon dioxide and glycogen of slices of heart

\begin{tabular}{|c|c|c|c|c|}
\hline \multirow{2}{*}{ Experiment } & \multicolumn{2}{|c|}{ Glucose-U- $\mathrm{C}^{14}$ to $\mathrm{CO}_{2}$} & \multicolumn{2}{|c|}{ 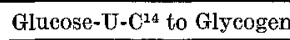 } \\
\hline & control & diabetic & control & diabetic \\
\hline \multicolumn{5}{|c|}{ Mildly diabetic } \\
\hline $\mathrm{T}-1$ & 1.6 & 2.4 & 0.10 & 0.15 \\
\hline B-2 & 1.4 & 1.6 & 0.45 & 0.26 \\
\hline \multicolumn{5}{|c|}{ Severely diabetic } \\
\hline 36 & 0.7 & 0.4 & 0.19 & 0.27 \\
\hline $\mathrm{D}-2$ & 2.9 & 0.5 & 0.31 & 0.23 \\
\hline CUV-A & 2.0 & 0.4 & 0.08 & 0.02 \\
\hline
\end{tabular}

Table 7. Incorporation (umoles/g/2 hours) of pyruvate-2- ${ }^{14} \mathrm{C}$ into carbon dioxide and glycogen of slices of kidney

\begin{tabular}{|c|c|c|c|c|}
\hline \multirow{2}{*}{ Experiment } & \multicolumn{2}{|c|}{ Pyruvate-2- $\mathrm{C}^{14}$ to $\mathrm{CO}_{2}$} & \multicolumn{2}{|c|}{ Pyruvate-2-C ${ }^{14}$ to glyeogen } \\
\hline & control & diabetic & control & diabetic \\
\hline \multicolumn{5}{|c|}{ Mildly diabetic } \\
\hline B-2 & 81 & 23 & 1.6 & 1.0 \\
\hline \multicolumn{5}{|c|}{ Severely diabetic } \\
\hline 36 & 65 & 21 & 3.7 & 2.7 \\
\hline CUV-A & 97 & 88 & 1.0 & 0.7 \\
\hline
\end{tabular}

tions are similar in both the normal and the diabetic. The incorporation into carbons 1,2 , and 3 are symmetrical with that into carbons 6,5 , and 4 except for a possible lower activity in 6 relative to the other carbons.

B. Morphology. The three animals with severe diabetes, 36, D-2, and CUV-A are included in the study of the renal glomerular lesions reported in a companion paper (SHIRAI, WELSH, and SIMS, 1967). All showed lesions believed to be out of proportion to changes that accompany aging in these animals. Hamster B-2 had changes in the glomeruli of the same nature, including capillary dilatation, as those of the animal of comparable age with severe diabetes, D-2, but of lesser severity, and osmophilic deposits were not seen in the capillary lumen. The changes seemed to be in excess of those in hamsters of comparable age without diabetes.

C. Comment. LANDAU (1960) found in alloxandiabetic rats increased uptake of pyruvate and increased incorporation into glucose by kidney over that of the control animals. An increase in incorporation into $\mathrm{CO}_{2}$ was not significant. As in the case of the present studies there was no increase in incorporation into glycogen. FlinN, Leboteuf and Camill (1961) found that the metabolism of glucose and mannose, but not of fructose, was markedly reduced in kidneys from alloxan-diabetic rats. In contrast to the present findings, oxidation of pyruvate to $\mathrm{CO}_{2}$ was slightly increased in kidneys from the diabetic animals. Glucose production was increased five-fold, and 75 per cent was estimated to be synthesized from pyruvate. The severity of the diabetes in two out of the three hamsters in the present study was comparable with that of the rats in the two previous studies.

From the distribution of radioactivity in the carbons of the glucose of the medium (as shown in Table 8) the following can be concluded. First, there is little if any difference in the extent of entrance of pyruvate carbon into the dicarboxylic acid shuttle of the Krebs cycle in the control compared with the diabetic hamsters. This is indicated by the similar randomization of ${ }^{14} \mathrm{C}$ into carbon 1 and 6 compared with carbons 2 and

Table 8. Per cent distribution of ${ }^{14} \mathrm{C}$ in glucose formed from pyruvate-2.14C by kidney

\begin{tabular}{|c|c|c|c|c|c|c|c|}
\hline $\begin{array}{c}\text { Carbons } \\
\text { Experiment }\end{array}$ & 1 & 2 & 3 & 4 & 5 & 6 & $\begin{array}{l}\text { Per cent } \\
\text { recovery }\end{array}$ \\
\hline $\begin{array}{ll}\text { B-2 } & \text { Control } \\
\text { Diabetic }\end{array}$ & $\begin{array}{l}18.3 \\
17.7\end{array}$ & $\begin{array}{l}18.4 \\
18.3\end{array}$ & $\begin{array}{l}13.5 \\
14.9\end{array}$ & $\begin{array}{l}15.5 \\
15.3\end{array}$ & $\begin{array}{l}18.3 \\
18.3\end{array}$ & $\begin{array}{l}15.9 \\
15.3\end{array}$ & $\begin{array}{l}117 \\
101\end{array}$ \\
\hline $36 \quad \begin{array}{l}\text { Control } \\
\text { Diabetic }\end{array}$ & $\begin{array}{l}17.7 \\
16.8\end{array}$ & $\begin{array}{l}18.8 \\
18.8\end{array}$ & $\begin{array}{l}13.8 \\
15.2\end{array}$ & $\begin{array}{l}16.2 \\
15.9\end{array}$ & $\begin{array}{l}18.5 \\
18.7\end{array}$ & $\begin{array}{l}15.0 \\
14.7\end{array}$ & $\begin{array}{l}115 \\
99.5\end{array}$ \\
\hline
\end{tabular}

incubation between 170 and $280 \mu$ moles/g of pyruvate was taken up by the kidneys from the control and diabetic hamsters. This represents an uptake of approximately 40 per cent of the added substrate. There was marked randomization of $\mathrm{C}-2$ of the pyruvate into glucose from the medium (Table 8). The distribu-
5 respectively. Secondly, there is a similar degree of oxidation of pyruvate via the Krebs cycle, and of fixation of $\mathrm{CO}_{2}$ by pyruvate as indicated by the randomization of ${ }^{14} \mathrm{C}$ into carbons 3 and 4 . Thirdly, very little carbon of pyruvate is converted to glucose of glycogen without first entering the Krebs cycle, since 
the activity in carbons 2 and 5 is only slightly greater than that of carbons 1 and 6 . There is a hint that a greater percentage of the pyruvate carbon is converted. directly to glycogen in the diabetic than control kidneys. That is for the control C2 minus $\mathrm{C} 1$ plus C5 minus $\mathrm{C} 6$ is 2.5 and 4.6 per cent and for the corresponding diabetic 3.6 and 6.0 It is perhaps noteworthy that for the liver (Table 4) the corresponsing values deviate in the same direction, that is 4.2 compared with 4.8 . The differences are so small that these conclusions cannot be made with any confidence. ting the presence of a ${ }^{14} \mathrm{C}$-containing contaminant in the sample. Nevertheless, there is randomization of ${ }^{14} \mathrm{C}$ consistent with pentose pathway activity in both control and diabetic. The calculated per cent of utilized glucose metabolized by this pathway is greater in the normal (12 and 14 per cent) than in the diabetic ( 6 and 9 per cent). The values are calculated from the formulae: $\frac{\mathrm{C}-1}{\mathrm{C}-2}=\frac{2 \mathrm{PC}}{1+2 \mathrm{PC}}$ and $\frac{\mathrm{C}-3}{\mathrm{C}-2}=\frac{\mathrm{PC}}{1+\mathrm{PC}}$ where $\mathrm{C} 1 / \mathrm{C} 2$ is the ratio of the specific activity in carbon 1 to 2 of glucose and $\mathrm{C} 3 / \mathrm{C} 2$ is the ratio in carbon 3 to that in

Table 9. Incorporation (umoles/g/2 hours) of glucose-2-14 $\mathrm{C}$ into $\mathrm{CO}_{2}$, lipid, fatty acids, and glycerol of epididymal fat tissue

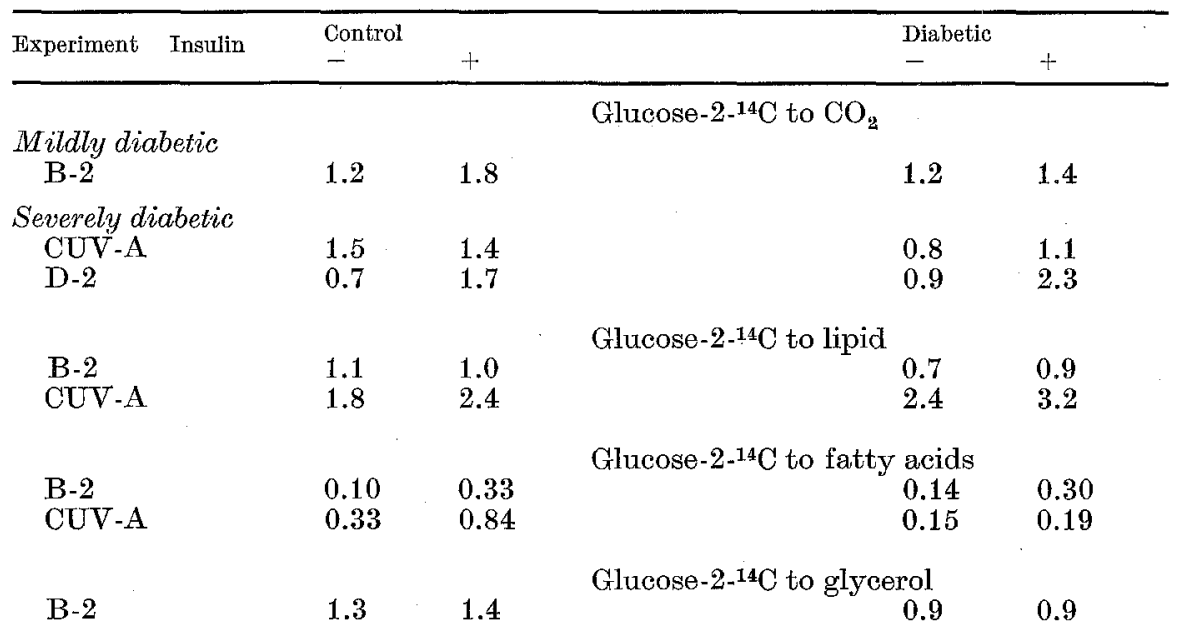

Table 10. Distribution of ${ }^{14} \mathrm{C}$ in glycogen from epididymal fat tissue after incubation with glucose-2- ${ }^{14} \mathrm{C}$ with carbon 2 set to 100

\begin{tabular}{lllrllll}
\hline Carbons & 1 & 2 & 3 & 4 & 5 & 6 & $\begin{array}{l}\text { Per cent } \\
\text { recovery }\end{array}$ \\
\hline $\begin{array}{l}\text { Control } \\
\text { Control with }\end{array}$ & 19.3 & 100 & 12.5 & 4.7 & 26.8 & 6.1 & 83 \\
insulin & 24.6 & 100 & 15.0 & 4.0 & 21.6 & 4.4 & 76.7 \\
$\begin{array}{l}\text { Diabetic (B-2) } \\
\text { Diabetic with }\end{array}$ & 10.0 & 100 & 8.5 & 2.4 & 19.4 & 3.2 & 74 \\
insulin & 20.5 & 100 & 11.6 & 3.0 & 20.9 & 7.2 & 87.7
\end{tabular}

\section{Adipose Tissue}

A. Biochemical. Only a few experiments could be performed because of the scarcity of adipose tissue, since in the severely diabetic hamsters essentially no adipose tissue was found. There was no difference in the oxidation and in the incorporation of glucose-

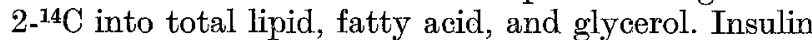
stimulated oxidation of the substrate into ${ }^{14} \mathrm{CO}_{2}$ and incorporation into total lipid. The latter incorporation was into the fatty acid and not the glycerol component. In one of the hamsters with mild diabetes the distribution of ${ }^{14} \mathrm{C}$ from glucose-2. ${ }^{14} \mathrm{C}$ in the carbons of the glucose from glycogen was determined in the presence and absence of added insulin (Table 10). Recovery of the sum of the ${ }^{14} \mathrm{C}$ in the individual carbons compared with the ${ }^{14} \mathrm{C}$ in the glucose sample was not good, indica- carbon $2 . \mathrm{PC}$ is the fraction of glucose utilized that is metabolized in the pentose cycle, i.e. is metabolized to $\mathrm{CO}_{2}$ and glyceraldehyde-3-phosphate. This percentage is increased by insulin in both normal and diabetic to 16 and 13 per cent respectively. The uptake of glucose in the experiments ranged from 4.8 to $6.2 \mu$ moles $/ \mathrm{g}$. When the weight of tissue, the volume of medium incubated, and the concentration of glucose in the medium are taken into account, this represents less than 25 per cent of the added glucose, so that glucose concentration changed little during the course of the ineubation.

B. Comment. A similar pattern of distribution of ${ }^{14} \mathrm{C}$ from glucose-2 ${ }^{14} \mathrm{C}$ has been observed by LaxDaU and KATz (1964) in glucose from glycogen of rat epididymal adipose tissue with an increase in randomization 
on addition of insulin. The decrease in randomization in the diabetic would then be consistent with insulin depletion. Such a conclusion is restricted by the limitation of the measurement and the fact that only a single experiment was carried out. Thus, except for the changes in randomization no change in adipose tissue metabolism as a result of diabetes has been observed. Because of the difficulties in studying adipose tissue from severe diabetes, this conclusion must be further restricted to mildly diabetic animals.

As in rat adipose tissue, insulin apparently enhances the oxidation of ${ }^{14} \mathrm{C}$ of glucose $-{ }^{14} \mathrm{C}$ to $\mathrm{CO}_{2}$ and its incorporation into fatty acids but not into glycerol.

\section{Discussion}

Conclusions with regard to the results just detailed are restricted by the limited number of animals. However, both the mild and severely diabetic hamsters have a reduction in the incorporation of the carbons of glucose and pyruvate into $\mathrm{CO}_{2}$, glycogen and fatty acids in the liver and, at least in the severely diabetic animals, of glucose into $\mathrm{CO}_{2}$ in muscle. There was no change consequent to diabetes in the metabolism of adipose tissue except for a possible decrease in pentose cycle activity. This could be a reflection of relative cellular starvation with respect to glucose, since restriction of carbohydrate in rats produces a rapid reduction in glucose-6-phosphate dehydrogenase and in 6-phosphogluconate dehydrogenase (HocLrFIELD and Parson, 1965). The kidneys of the diabetic hamsters had less incorporation of carbon 2 of pyruvate into $\mathrm{CO}_{2}$, but otherwise no biochemical changes were evident. Both muscle and adipose tissue were responsive to insulin in vitro when added in amounts in excess of the physiological.

Thus during the stages of diabetes in which the hamsters of this series were studied, the changes paralleled those seen in chronic insulin deficiency, as is seen in alloxan-diabetic rats (FuinN, CAHTru and LeBotur, 1961; LaNdAU, Hastings and NesbetT, 1955; MoRIwaki and LANDAU, 1962) and in acute deficiency as in rats given anti-insulin serum (KALKHOFF and KTPNIS, 1966; WAGLE and Ashyore, 1963). However, although an attempt was made to study the hamster in detail at the earliest onset of the disorder when the primary mechanism should be most apparent, it is quite possible that such an early stage was missed. Nevertheless, in our few hamsters with the mildest diabetes the pancreas was seen by electron microscopy to be lightly granulated and in one the extractable insulin was reduced. In the same animal, in spite of hyperglycemia, the plasma insulin did not exceed that of the control, suggesting a relative hyposecretion of insulin. Furthermore, CARPENTER et al. (1967) have reported that in non-glucosuric siblings of diabetic hamsters, which presumably represent the earliest stage of the disorder, there is reduction in volume and in number of granules of the beta cells of the islets. In spontaneous diabetes in other species there has been postulated an aberration of metabolism of one or more tissues or an antagonist to the action of insulin, which acts at the level of the tissue or of the plasma, which leads to initial pancreatic hypertrophy and hypersecretion of insulin. To exclude completely the possiblity that there is a transient stage of this sort in the hamster, further studies of hamsters with wellcharacterized early diabetes are necessary.

In the diabetic hamsters of this series particular attention was given as well to electron microscopic studies of the small vessels of the pancreas. Gonet et al. (1966) have noted in the spiny mouse (Acomys cahirinus) in the presence of very early hyperglycemia a thickening of the basement membrane of the capillaries in this location. There was no evidence in our series that thickening of the basement membranes of the capillaries adjacent to islets was a barrier to release of insulin. Microscopic changes in the glomeruli in excess of those to be expected from aging alone were found in those animals with severe diabetes. These changes are described in a companion paper (ShiraI, WeLsir and Stms, 1967).

Acknowledgements. The authors are indebted to Dr. GeoRGE W. WeLSH, 3rd, for having made available diabetic hamsters from the colony at the University of Vermont, which was started with animals kindly supplied by Dr. George Yergantan, and to Dr. OtTo StreiK of the University of Toronto for supplying hamster T-1. Renzo NyLANDER, B.S., and MARYANN LoRenz, R.N., contributed to the care and breeding of the hamsters. They are particulary indebted to Hoctis WILLIAMs, B.S., for carrying out degradations of glucose for distribution of radioactivity, and to RUTH FRINK, B.S., for electron microscopic studies of the pancreas. Dr. Roy Konson evaluated light and electron microscopic sections of the pancreas. The hamster colony was supported by USPHS grant AV- 05748 from the National Institutes of Arthritis and Metabolic Disease. One of us (E.A.H. Srms) was supported by a fellowship from the Commonwealth Fund of New York. Additional support was provided by a grant-in-aid from the American Heart Association.

\section{References}

Ashmore, J., J.H. Kinoshtta, F.B. Nesbett and A.B. Hastings: Studies on carbohydrate metabolism in rat liver slices; evaluation of Embden-Meyerhof and phosphogluconate oxidation pathways. J. biol. Chem. 220, $619-626(1956)$.

- G.F. Cahili, JR., A.B. Hasmings and S. ZotTu: Studies on carbohydrate metabolism in rat liver slices. VIII. Effect of ions and hormones on pathways of glucose-6-phosphate metabolism. J. biol. Chem. 224, 225235 (1957).

Betott-Chatn, A., R. Catanzaro, E.B. Cham, L. Mast, F. Pocchiari and C. Rossi: Influence of insulin on carbohydrate metabolisin in isolated diaphragm musclo in normal and alloxan diabetic rats. Proc. roy. Soc. London, B. 143, 481-503 (1955).

CARtson, L.A., and L.B. WADström: Determination of glycerides in blood serum. Clin. chim. acta 4, 197-205 (1959).

Carpenter, A.-M., G.C. Gerritsen, W.E. Dutro and A. Lazarow: Islet and Beta Cell Volumes in Diabetic Chinese Hamsters and their Non-Diabetic Siblings. Diabetologia $3,92-96$ (1967). 
ComæN, P.P.: Suspending media for animal tissues: In "Manometric Techniques". Ed UMBReIt, W.W., R.H. Burris and J.F. StaufFer. p. 149. Minneapolis: Burgess Publishing Co. 1959.

FitnN, R.B., R. LeBoetr, G.F. Cahtu, JR.: Metabolism of ${ }^{14} \mathrm{C}$-labeled substrates in kidney cortical slices from normal and alloxan-diabetic rats. Amer. J. Physiol. 200, 508-510 (1961).

Gonet, A. E., W. Stauffacher, R. Pictet and A. E. RENOLD: Obesity and diabetes mellitus with striking congenital hyperplasia of the islets of Langerhans in spiny mice (Acomys cahirinus). I. Histological findings and preliminary metabolic observations. Diabetologia 1, 162-171 (1965).

Hackel, D.B., L.A. Frohman, E. Mtkat, H.E. LeboVITZ, K. SCHMTDT-NIELSEN and T. D. KINNEY: Review of current studies on the effect of diet on the glucose tolerance of the sant rat (Psammomys obesus). Ann. N.Y. Acad. Sci. 131 (Art. 1), 459-463 (1965).

Hastings, A.B., C.-T. Teng, F.B. NesberT and F.M Sintx: Carbohydrate metabolism in rat liver slices. I. The effect of cations in the media. J. biol. Chem. 194, $69-81(1952)$.

Hollifield, G., and W. Parsons: "Effect of feeding on fatty acid synthesis." In "Handbook of Physiology, Section 5: Adipose Tissue." Reroud, A.E., and G.F. CAHILL, JR., eds. pp. 393-398. Washington, D.C. : American Physiological Society 1965.

KaLконFF, R.K., and D.M. KIPNIS : Studies of the metabolic effects of acute insulin deficiency I. Mechanism of impairment of hepatic fatty acid and protein synthesis. Diabetes 15, $443-450$ (1966).

- K.R. HorNBrooK, H.B. BURCH and D.M. KIPNIS: Studies of the metabolic effects of acute insulin deficiency. II. Changes in hepatic glycolytic and Krebscycle intermediates and pyridine nucleotides. Diabetes $15,451-456$ (1966).

LaBuschagne, C.J., B.K. Hafsstg and G.A. WrenSHALL: Factors influencing the amount of insulin extractable from beef pancreas. II. Effects of altering the extraction procedure on the changes in the insulin extractable from aging pancreas and on recovery of insulin. Canad. J. Biochem. 35, 537-543 (1957).

LANDAU, B.R., A. B. HASTINGS and F.B. NesBetT: Origin of glucose and glycogen carbons formed from ${ }^{14} \mathrm{C}$-labeled pyruvate by livers of normal and diabetic rats. J. biol. Chem. 214, $525-535$ (1955).

- Gluconeogenesisand pyruvate metabolism in rat kidney, in vitro. Endocrinology 67, 744 - 751 (1960).

- and J. Katz: Pathways of glucose metabolism. In "Handbook of Physiology, Section 5: Adipose Tissue." RENOLD, A.E., and G.F. CAHILL, JR., eds. pp. 253 271. Washington, D.C.: American Physiology Society 1965 .
- G. W. BaRTSCH and H. R. Williams: Estimation of the glucuronic acid pathway contribution to glucose metabolism in adipose tissue and the effect of growth hormone. J. biol. Chem. 241, 750-760 (1966).

LeONARDS, J.R., B.R. LANDAU and G.E. BARTSCH: Assay of insulin-like activity with rat epididymal fat pad. J. Lab. clin. Med. 60, 552-570 (1962).

Luse, S.A., F. Caramia, G. Gerritsen and W. Dulin: Spontaneous diabetes mellitus in the Chinese hamster: An electron microscopic study of the islets of Langerhans. Diabetologia 3,97-108 (1967).

MoRIwaki, T., and B.R. LANDAC: Fructose and glucose metabolism in the normal and diabetic rat diaphragm in vitro. Arch. Biochem. 97, 544-550 (1962).

Pease, D.C.: Histological Techniques for Electron Microscopy. New York: Academic Press, 2nd edition 1965.

Renold, A.E., G.R. Zahnd and J. Christophe: Discussion by Dr. Renold "Spontaneous diabetes mellitus in the Chinese hamster, Cricetulus griseus, IV. Genetic Aspects," by G. Yerganian in Ciba Foundation Colloquia on Endocrinology, 15, pp. 42-43. Boston: Little, Brown and Company 1964.

Surrar, T., G.W. Wretsh, 3rd and E.A.H. Srms: Diabetes in the Chinese hamster. II. The evolution of glomerulopathy. Diabetologia 3, 266-286 (1967).

SOELDNER, J.S., and D. Slone: Critical variables in the radioimmunoassay of serum insulin using the double antibody technic. Diabetes 14, 771-779 1965).

Somogyi, M.: Notes on sugar determination. J. biol. Chem. 195, 19-23 (1952).

Vimlee, C.A., and A.B. Hastings: The metabolism of ${ }^{14} \mathrm{C}$-labeled glucose by the rat diahpragm in vitro. J. biol. Chem. 179, 673-687 (1949).

WAGLE, S.R., and J. AsHMORE: Studies on experimental diabetes. II. Carbon dioxide fixation. J. biol. Chem. 238, 17-20 (1963).

Wasko, M.E., and E.W. RICE: Determination of glucose by an improved enzymatic procedure. Clin. Chem. 7, $542-545(1961)$.

YALOW, R.S., and S.A. Bersox: Immunoassy of endogenous plasma insulin in man. J. clin. Invest. 39, $1157-1175(1960)$

Ymrganian, G., B. Mackay and H.J. GagnoN: The first ten generations of brother-sister matings of the Chinese hamster. (Abstract). Geneties 40, 403 (1957).

YmRGanian, G.: Spontaneous diabetes mellitus in the Chinese hamster, Cricetulus griseus. IV. Genetic aspects. In "Aetiology of Diabetes and Its Complications". Ciba Foundation Colloquia on Endocrinology. 15. pp. 2541. Boston: Little, Brown and Company 1964.

Dr. Ethan A.H. Stms

Department of Medicine

Medical Alumni Building

University of Vermont

Burlington, Vermont 05401, U.S.A 